\title{
Mediating Role of Company Size on Earnings Per Share and Price to Book Value
}

\author{
Julia Safitri ${ }^{1, *}$, Muhamad Arief Affandi ${ }^{2}$ \\ ${ }^{1}$ Faculty of Economics, Terbuka University Indonesia \\ ${ }^{2}$ Civil Servant at the Ministry of Home Affairs, the Republic of Indonesia \\ julialecampus.ut.ac.id
}

\begin{abstract}
Earnings Per Share (EPS) is calculated by dividing net income by the number of outstanding shares (Shares outstanding). When evaluating a company's success, investors must consider how changes in income affect their investment. This study will examine the impact of the revenue per offer and profit strategy on firm value. This study focused on LQ45 companies listed on the IDX from 2012 to 2019. Using the purposive inspecting strategy with information accessibility measures, 300 organizations were found. This study uses SEM-PLS with WarpPLS 7.0. The study's findings show that while profits per share and dividend policy have no direct impact on the price to book value, they have a considerable impact when mediated by size as an intervening variable. This shows that if expanding company value is based on increasing profits, then the signal theory can explain if growing corporate assets enhance company worth. to recruit investors to the firm.
\end{abstract}

Keywords: earning per share, signaling theory, price to book value

\section{INTRODUCTION}

Numerous elements contribute to a company's worth, one of which is the price-earnings ratio. This ratio indicates how much investors value shares with profits per share multiples (Cahyaningrum \& Antikasari, 2017). Earnings Per Share is the profit earned by the business divided by the number of outstanding shares (Almeida, 2019). Earnings Per Share (EPS) growth should be followed by a unidirectional increase in Price to Book Value (PBV) (PBV). The higher the Earnings Per Share, the more profit the firm earns; on the other hand, the lower the Earnings Per Share, the less profit the company makes. The purpose of an organization is to increase the organization's value or abundance for investors. Amplifying the organization's value entails increasing the current value of all future advantages investors receive. The organization's worth is reflected in a stable stock price that has grown through time, with the higher the stock price, the greater the organization's capital (Bratamanggala, 2018).

Earnings Per Share (EPS) is the result of the organization's overall profit (Net Income) divided by the number of outstanding shares (Shares outstanding) (Khalaf Taani, 2011). The higher the Earnings Per Share, the more profit the company earns. When investors analyze a company's performance, it is not sufficient to know whether its income has increased or reduced; investors must also consider the impact of income changes on their investment. Established businesses typically have a high Earnings Per Share ratio, whereas fledgling companies usually have a low Earnings Per Share (EPS). Profitability is a metric used to determine whether a business's finances have improved or deteriorated, specifically through comparisons to the prior period (Sadeghi Lafmejani, 2017). Changes in this growth or decline affect subsequent financial policies, such as those governing the determination of dividends, debt repayment, allowances, and reinvestment to ensure the company's operations continue.

As explained in the Bird in hand theory, the relationship between dividends and firm value is that profits earned will be more valuable if distributed. Thus it is preferable to pay the maximum profit to shareholders rather than holding back, which will not necessarily improve shareholders' welfare (Lintner \& John, 1956). On the other hand, dividend payments can be utilized to mitigate disputes between managers and shareholders as owners (Jensen \& Meckling, 1976). Due to the asymmetric information, dividends can be used to communicate and signal financial performance to outside shareholders (Bhattacharya, 2007).

The research void in this study is the void in the relationship between profits per Share and business value. Numerous research has concluded that earnings per Share harm company value, while others end that earnings per Share positively impact firm value following (Chen et al., 2015). Earnings per Share (EPS) is widely regarded as the primary factor determining stock prices and corporate value. The literature demonstrates that most individual financial backers base their speculative decisions on EPS (Islam et al., 2014). This study establishes that EPS increases company value as evaluated by PBV. 
Additionally, earnings per Share have a favourable effect on business value (Bratamanggala, 2018). According to the study's findings (Alduais, 2020; Hanifah, 2019), earnings per Share negatively affect business value. This study aims to conduct a search and analysis of the influence of profits per share and dividend policy on firm value when firm size is considered.

\section{LITERATURE REVIEW AND HYPOTHESES DEVELOPMENT}

The signal theory demonstrates that successful businesses use financial data to communicate with the market (Ross et al., 2007). The signal theory elucidates why firms are prone to provide economic report data to external gatherings. Signal theory demonstrates the existence of information asymmetry or the fact that the information received by management and interested parties is not identical. The board of directors has a greater understanding of the business and its potential than invested individuals such as financial backers and leasers. As a result, managers prepare financial statements to educate these interested parties.

Agency Theory (Jensen and Meckling, 1976) establishes that an agreement exists between the administrator (expert) and proprietor (head). To ensure that this legally obligated connection operates smoothly, the proprietor will designate the chief to a dynamic position. Thus, managers are more knowledgeable about the ins and outs of the business than the owner. According to (Eisenhardt 1989), the agency relationship establishes a distinction between ownership (principal), represented by shareholders, and controlling party (agent), represented by managers who operate the business.

According to (Gollin et al., 1999), the business size is a scale that indicates whether a firm is large or tiny based on its stock market valuation, total assets, and $\log$ size. Essentially, organizations are classified according to their size into three categories: gigantic, medium, and trim. The assurance of an organization's size is contingent upon the organization's total resources. (Brigham and Houston, 2016) A company's size is determined by its total asset value, total sales, total profit, and tax expense, among other factors. The larger a bank is, the more profit it earns. Because huge corporations can readily leverage their scale to deal

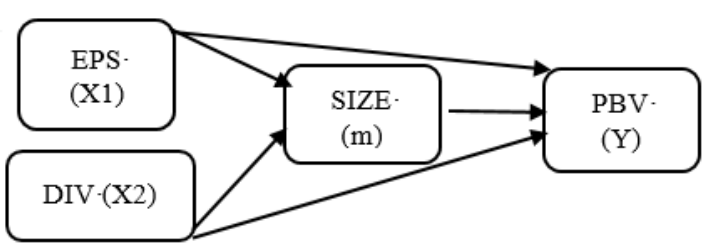

with other financial sector stakeholders. Figure 1 illustrates the framework of cognition.

Fig 1. Thinking Framework

From the description above, the hypothesis is built as follows:

H1: Earning per share (EPS) has a positively impact on PBV

H2: Dividends have a positively effect on PBV

H3: Size can mediate the effect of earnings per share on PBV

H4: Size can mediate the effect of dividend relationship on $\mathrm{PBV}$

H5: Size has a positively effect on PBV

\section{RESEARCH METHOD}

The population consists of 45 firms' members of the LQ45 Index and are listed on the Indonesia Stock Exchange. LQ45 businesses are 45 issuers selected based on their high liquidity (Liquidity) and a variety of other factors. These criteria may take market capitalization into account. The sampling technique was carried out using the purposive inspecting strategy established to obtain a delegate test with the following measures: (1) Companies included in the LQ45 Index between 2012 and 2019, (2) Companies that submitted financial statements on the LQ45 Index regularly during that period. Between 2012 and 2019, 300 companies met the purposive sample criteria, but 15 companies were excluded due to their failure to routinely submit financial results on the LQ45 Index throughout that period.

\subsection{Independent Variable (X)}

According to (Ghaeli 2017), the Price Earnings Ratio illustrates the period required to return assets at the level of stock costs and friend advantages over a period. The Value Earnings Ratio indicates the financial supporters' willingness to pay a set amount for each rupiah of profit generated by the firm.

$$
\text { Earning Per Share }=\frac{\text { Net Profit }}{\text { Listed Share }}
$$

Dividend Payout Ratio (DPR): it's the percentage of a company's net profit distributed to shareholders.

$$
\mathrm{DPR}=\mathrm{DPS} / \mathrm{EPS}
$$

\subsection{Intervening Variables}

A company's assets are its property or resources. The greater the company's asset base, the more equipped it can invest wisely and meet product demand. This 
increases the company's market share and affects its profitability.

Size of Firm $=$ Ln Total Aset

\subsection{Dependent Variable}

Price to Book Value is the examination between the cost per share and the book esteem per share. PBV is determined with the accompanying detailing:

\subsection{Data Analysis Technique}

$$
\text { Priceto Book Value }=\frac{\text { Price per Share }}{\text { Book Value Share }}
$$

The information research strategy used in our work was Structural Equation Modeling (SEM) utilizing the instrument Partial Least Squares (PLS) WarpPLS 7.0. As a result, our evaluation is both predictive and exploratory. The utilization of PLSSEM has a few advantages, including the capacity of SEM-PLS to operate effectively with little example complexes and models, and the presumption of information appropriation in SEM-PLS is moderately looser than that of other procedures, for example, $\mathrm{CB}$ (Covariance-based)-SEM.

\section{RESULTS AND DISCUSSION}

The proposed model is fit since an AFVIF value of 1.097 and an AVIF value of 1.023 support it. Additionally, because it is less than 3.3, there is no multicollinearity. Meanwhile, the model forecast is quite large due to the $0.410 \mathrm{GoF}$ value (greater than 0.36) (Table 1.2).

Table 1. Fit . Research Model

\begin{tabular}{lc}
\hline Provisions & Conclucion \\
\hline Avrge path coefficient $(\mathrm{APC})=0.196$, & FIT \\
$\mathrm{P}=0.011$ & FIT \\
Avrge block VIF (AVIF) $=1.023$. & \\
acceptable if $<=5$, ideally $<=3.3$ & FIT \\
Avrge full collinearity VIF & \\
(AFVIF) $=1.097$, acceptable if $<=5$, & \\
ideally $<=3.3$ & \\
Avrge R-squared (ARS) $=0.168, \mathrm{P}=0.022$ & FIT \\
Avrge adjusted R-squared & FIT \\
(AARS) $=0.146, \mathrm{P}=0.035$ & \\
Tenenhaus GoF $(\mathrm{GoF})=0.410$, small $>=$ & FIT \\
0.1, med. $>=0.25$, large $>=0.36$ & \\
\hline
\end{tabular}

Table 2. Full Colinearity VIF Test, Adjusted R Squared and R Squared, Q-squared

\begin{tabular}{lrrrr}
\hline & EPS & SIZE & DIV & PBV \\
\hline Full collinearity & 1.051 & & & \\
& 1.169 & 1.153 & 1.014 & \\
R-Squared & & & 0.158 & 0.178 \\
\hline
\end{tabular}

\begin{tabular}{lll}
\hline Adj R Squared & 0.140 & 0.151 \\
Q-Squared & 0.168 & 0.182 \\
\hline
\end{tabular}

As can be seen from the table above, the model is devoid of horizontal collinearity issues and is generally classified as having a high degree of accuracy. The total collinearity value is $3.3(<\mathbf{3 . 3})$ (Table 3).

Table 3. Results of path coefficient and P-Value

\begin{tabular}{lrr}
\hline Path Description & Path Coefficient & P-Value \\
\hline $\mathrm{EPS} \rightarrow \mathrm{PBV}$ & 0.006 & 0.477 \\
$\mathrm{DIV} \rightarrow \mathrm{PBV}$ & 0.051 & 0.305 \\
$\mathrm{SIZE} \rightarrow \mathrm{PBV}$ & 0.412 & $<0.001$ \\
$\mathrm{EPS} \rightarrow$ SIZE & 0.186 & 0.028 \\
\hline
\end{tabular}

The first hypothesis (H1) was rejected because the pvalue is 0.477 and the coefficient is 0.006 , implying that EPS does not affect the PBV. The second hypothesis (H2) was also dismissed because the pvalue is more significant than 0.05 and 0.305 , and the coefficient is 0.051 (Figure 2). This means that dividends (DIV) do not affect the PBV. Moreover, with a coefficient value of 0.186 and a p-value of 0.028, the third hypothesis is accepted: EPS has a positive effect on PBV through volume. Other results show that size partially successfully mediates the relationship between the impact of DIV (dividends) and EPS on PBV, with a coefficient of 0.324 and a pvalue of 0.001 (Table 4).

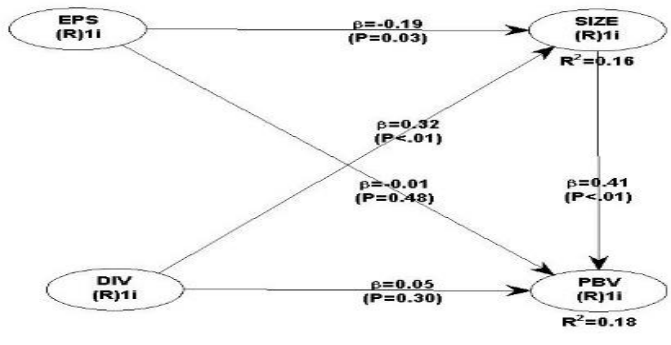

Fig. 2. Full research model

Table 4. Indirect Effect and Total Effect

\begin{tabular}{lll}
\hline Indirect effect & $\begin{array}{l}\text { Path } \\
\text { coefficient }\end{array}$ & P-value \\
\hline $\mathrm{EPS} \rightarrow \mathrm{SIZE} \rightarrow \mathrm{PBV}$ & 0.139 & 0.028 \\
$\mathrm{DIV} \rightarrow$ SIZE $\rightarrow$ PBV & 0.133 & 0.077 \\
$\mathrm{~T}$ otal effect & Path coefficient & P-value \\
$\mathrm{EPS} \rightarrow \mathrm{SIZE} \rightarrow$ PBV & 0.186 & 0.029 \\
$\mathrm{DIV} \rightarrow$ SIZE $\rightarrow$ PBV & 0.412 & $<0.001$ \\
\hline \multicolumn{2}{c}{$\mathrm{O} \quad$ Source: } & WarpPLS 7.0 data processing
\end{tabular}

The data processing results show that the SIZE value can significantly moderate the effect of EPS on PBV. This is demonstrated by testing the mediating product in the table above. The indirect effect coefficient for testing the EPS SIZE PBV mediation hypothesis is 
0.139 with a p-value of 0.028 (p 10\%). In addition, DIV SIZE PBV is 0.133 with a $p$-value of 0.077 . It is possible to conclude that DIV and PBV have a partial mediation relationship via SIZE as a partial mediating variable. Suppose EPS SIZE PBV has a coefficient value of 0.186 and a p-value of 0.029 . In that case, DIV SIZE PBV has a coefficient value of 0.412 and a p-value of 0.001, and SIZE successfully mediates the relationship between the two variables. According to the study's findings, the first hypothesis, which states that earnings per share positively affects firm value, is consistent with research conducted by (Alduais 2020; Hanifah, 2019), which explains that earnings per share harm enterprise value. It is understandable. When evaluating a company's performance, it is not enough for investors to know whether a company's income has increased or decreased; investors must also consider how changes in income affect their investment. In general, well-established companies have a high Earnings Per Share (EPS) ratio, whereas young companies have a low EPS tendency. However, the two independent variables have proven to be significant, with firm Size serving as a mediator between the two on firm value. This demonstrates that firm Size is a factor in how well executives deal with the organization, affecting substantial worth.

Furthermore, after data processing and mediation testing, Size's role as a mediator of the relationship between the influence of Earnings Per Share and dividend policy on Price to Book Value partially mediates the relationship between the impact of Earnings Per Share and dividend policy on Price to Book Value. This is demonstrated if the influence of company size is one of the most critical factors that the company must consider. The Size of the company's value is determined by its Size.

\section{CONCLUSION AND RECOMMENDATION}

The purpose of this review is to investigate and assess the impact of the relationship between profit per offer and profit strategy on firm value. This study focused on LQ45 firms listed on the IDX between 2012 and 2019. The purposive sampling method and data availability criteria were used to sample 300 organizations. The analytical instrument in this study was SEM-PLS with WarpPLS 7.0 application. The review's findings show that, while the influence of profits per share and dividend policy on price to book value is small, the relationship between earnings per share and dividend policy on price to book value has a significant effect when size acts as a mediating factor. This demonstrates that the company's size has an impact on its value. The company's scope is defined by its assets, and signal theory may explain whether the increase in company value is due to the firm's performance in creating profits, which affects expanding its support and thus increasing its worth.

\section{REFERENCES}

1. Alduais, F. (2020). An empirical study of the earningsreturns association: an evidence from China's A-share market. Future Business Journal, 6(1). https://doi.org/10.1186/s43093-020-0010-8

2. Almeida, H. (2019). Is it time to get rid of earnings-pershare (EPS)? Review of Corporate Finance Studies, 8(1), 174-206. https://doi.org/10.1093/rcfs/cfy010

3. Bhattacharya, S. (2007). Imperfect information , dividend policy, and " the bird in the hand " fallacy. The Bell Journal OfEconomics, 10(1), 259-270.

4. Bratamanggala, R. (2018). Factors affecting earning per share: The case of Indonesia. International Journal of Economics and Business Administration, 6(2), 92100. https://doi.org/10.35808/ijeba/160

5. Cahyaningrum, Y. W., \& Antikasari, T. W. (2017). Pengaruh Earning Per Share, Price To Book Value, Return on Asset, Dan Return on Equity Terhadap Harga Saham Sektor Keuangan. Jurnal Economia, 13(2), 191. https://doi.org/10.21831/economia.v13i2.13961

6. Chen, L. W., Yu, H. Y., \& Huang, H. H. (2015). Revisiting the earnings-price effect: The importance of future earnings. Finance Research Letters, 13, 90-96. https://doi.org/10.1016/j.frl.2015.02.009

7. Eisenhardt, K. M. (1989). agency theroy. The Academy of Management Review, 14(1), 57-74.

8. Ghaeli, M. R. (2017). Price-to-earnings ratio: A stateof-art review. Accounting, 3(2), 131-136. https://doi.org/10.5267/j.ac.2016.7.002

9. Hanifah, A. (2019). The Effect of Earning Per Share (EPS), Price Earning Ratio (PER) and Price Book Value (PBV) Against the Stock Price of Telecommunications Sector Company Included in the Indonesian Islamic Stock Index (ISSI). KnE Social Sciences, 2019, 711-726. https://doi.org/10.18502/kss.v3i26.5410

10. Islam, M. R., Khan, T. R., Choudhury, T. T., Adnan, A. M., \& Senior Lecturer, 1. (2014). How Earning Per Share (EPS) Affects on Share Price and Firm Value. European Journal of Business and ManagementOnline), 6(17), 2222-2839.

11. Jensen, C., \& Meckling, H. (1976). Theory of The Firm: Managerial Behavior, Agency Costs and Ownership Structure. Introduction and summary In this paper WC draw on recent progress in the theory of (1) property rights, firm . In addition to tying together elements of the theory of e. Journal of Financial Economics, 3(7), 305-360.

12. Khalaf Taani, M. H. H. B. (2011). The Effect of Financial Ratios, Firm Size and Cash Flows From operating activities on Earnings Per Share: (An applied Study: on jordanian Industrial Sector). International Journal of Social Sciences and Humanity Studies, 3(1), 197-205.

13. Lintner, \& John. (1956). Distribution of Incomes of Corporations Among Dividens, Retained Earnings, 
and Taxes John Lintner The American Economic Review, Vol . 46, No . 2 , Papers and Proceedings of the Sixty-eighth Annual Meeting of the American Economic Association . ( May ,. The American Economic Review, 46(2), 97-113.

14. Ross, S. A., Bell, T., Spring, N., \& Ross, S. A. (2007). The determination of financial structure : the incentive- signalling approach. The Bell Journal OfEconomics, 8(1), 23-40.

15. Sadeghi Lafmejani, M. A. (2017). The relationship between size, book-to-market equity ratio, earningsprice ratio, and return for the Tehran stock Exchange. Accounting, 3 , https://doi.org/10.5267/j.ac.2016.6.002
$11-18$. 